\title{
ECOFEMINIST DISCOURSE AND ECO ART
}

\author{
Nezaket Tekin ${ }^{\mathrm{i}}$ \\ Dokuz Eylul University, \\ Turkey
}

\begin{abstract}
:
This article focuses on the concepts of woman-nature-art, 18.-19. Century has progressed through a structure that extends from women nature artists to today's eco art. First of all, female protagonists in the stories of the writer Andrea Barrett and their historical counterparts, such as Elizabeth Blackwell, were included. Examples of the works of female artists who criticized the male predominance in the art environment of the 1970s were examined. At the same time, it was mentioned that awareness of the environment increased in the 1970s with the influence of scientists, activists and artists. The concept of Ecofeminism, which was first used by Françoise d'Eaubonne in 1974, was defined, and the women and ecology connections of writers such as Vandana Shiva were mentioned. In the last two sections, the works of the women artists selected were examined with the descriptive method. Agnes Varda is discussed in her wheat field project, which she cultivates in the commercial center of New York, as she is the first artist to engage in agriculture as an artistic act and production. Katie Holten has made boulevard trees visible using photographs, drawings, maps, interviews and software. Finally, there is Neri Oxman, who uses nature itself as a design in her projects, which she calls "Material Ecology" combines science, engineering, art and design.
\end{abstract}

Keywords: women in nature art, Andrea Barrett, ecofeminism, eco art, Neri Oxman

\section{Introduction}

In Greek mythology, Gaia is the goddess of the earth, who created everything. It is Mother Earth. In many cultures, the soil is fertile and feminine. The Age of Enlightenment saw the human mind superior to nature and used it for their own interests. Modernization and industrial society were formed as a result of this mindset. However, unfortunately, both nature and women are ignored in this view where reason is at the forefront. Nature has become a field that should be used for the interests and needs of human beings, and women are seen as second-class citizens who cannot have an opinion on this issue. In this process, women were accepted as the people who ensure the reproduction of the lineage and ensure the order of the family in the home. The maledominated perspective ignored women and their intelligence. The only area where women could open up was the nature around their living spaces. Women, who conveyed the painting lessons,

' Correspondence: email nezocat@gmail.com 
one of the rare educations they could take at home, through their observations in the nature walks, and who could put this into practice both artistically and scientifically, are now known in history. Although the 19th and 20th centuries are seen as the age of inventions and technological progress, the understanding that uses the knowledge of nature as an endless source of wealth has gone bankrupt today. The resources of the world are at the stage of depletion and its impact threatens human beings as well as all living things. Studies carried out in this context have necessitated the meeting of science, politics, economy and art on a common ground. Our sensitivities and awareness have increased, as the 21st century's development in communication technologies has made possible a flow of information in a global context. One of the most powerful organs that conveys the awareness that we need to restructure is art. Today, most artists have turned into individuals who examine the problems of the age we live in and offer solutions. For this reason, artists have developed new expression possibilities by using science and technology. On the other hand, the effect of women who have been suppressed for centuries in science and art, and in fact, the side of women, which has been damaged by the maledominated perspective, has begun to be visible in today's ecological art. The theory of ecofeminism has found its place as a powerful theory in describing nature and contemporary ecological problems.

\section{Women in Nature Art}

In the historical fiction genre of writer Andrea Barrett's stories about nature and science, female characters take place as an important figure. Most of the stories in her book "Ship Fever" were fictionalized by people who were interested in natural science in 19th century Europe. One of these stories, "Rare Bird", takes place in London in 1762. Sarah Anne and her older brother Christopher were raised "like two boys" by their father since their mother died and spent their childhood learning the names of plants and birds in nature. Everything changes when Sarah Anne turns twenty-nine:

"Sarah Anne has inherited her father's brains but Christopher inherited everything else, including his father's friends. Sarah Anne acts as hostess to these men, at Christopher's bidding. In part she's happy for their company, which represents her only intellectual companionship. In part she despises them for their lumbago and thinning hair, their greediness in the presence of good food, the stories they repeat about the scientific triumphs of their youth, and the fact that they refuse to take her seriously. Not one of them has done anything original in years." (Barrett, 2018: 59).

As seen in the character of Sarah Anne, in the 1700s, there was a prevailing view that men were superior to women, that women were not smart enough for science, which was the domain of men, and that it was inappropriate for women to be interested in science. The daughters of wealthy families receive education at home only in subjects such as art, music and language. One of the women who has come to the fore in the world of men with her success is the herbalist Elizabeth Blackwell (1707-1758), the creator of the book "A Curious Herbal", in which she made her own drawings and print engravings based on real examples. "The book, in which 500 medicinal 
plants used in medicine in the 1700s, along with traditional information on which diseases they are good for, plant-specific prescriptions and preparation methods, won the admiration of many physicians, botanists and pharmacists, especially in London." (Kapucu, 2021). There have been other women who study botany because family members are interested or because gardening and nature walks may be suitable for women. For example, German Maria Sibylla Merian (1647-1717) started by painting garden flowers and later went into botanical history as the first entomologist. The works of women artists who contributed to botany such as Barbara Regina Dietzsch, Lise Cloquet, Lady Brassey and other names can be examined at the Oak Spring Garden Foundation. (OSGF, 2021). Another woman botanist and photographer Anna Atkins (1799-1871) has an important place in the history of photography. As in other examples, there are similar conditions for Atkins to be successful in botany. She lost her mother at a young age, working with her father, a respected scientist at the British Museum, to draw illustrations of mussel shells and plants. After their marriage, they met closely with Henry Fox Talbot, who invented many photographic methods. In this way, she gets a camera. In photography history books, Anna Atkins is thought to be the first female photographer, but none of the calotypes she took have survived. However, "Photographs of British Algae: Cyanotype Impressions" (1843) is extremely important for the history of photography, as it is the first book to include botanical images obtained by the cyanotype photographic method. In the cyanotype method, the form of the plant is white, while the other parts are blue (cyan). This magnificent book is available at the London Natural History Museum and its website (Lotzof, 2021).

\section{Ecofeminism Approach}

In the 20th century, women who took the place of men who participated in the First World War started to work in every field and continued to work after the war due to the high losses. The self-confidence brought by the active lives of women outside the home is also reflected in culture and art. Women's clothing styles have changed, long skirts have been replaced by trousers and attractive dresses. Female photographers such as Dora Maar, Claude Cahun and Lee Miller stood out with their courage and unique looks. In the 1960s, women's discourses on freedom, equality and seeking rights reflect the influence of feminist theory. While art critic Linda Nöchlin was trying to draw attention to the subject with her article titled "Why Aren't There Great Women Artists" written in 1971, artist Eleanor Antin started her photography work called "100 Boots" (1971-73). We see 50 pairs of men's boots lined up in front of different places in the city. One of these places is in front of the modern arts museum. Antin's photographs show the irony of male dominance in the art market, as in many areas of life. (Tekin, 2002: 87-88). Although the ratio of female and male students in Fine Arts Faculties is close to each other, it is more difficult for female artists to find a gallery to represent them when they graduate. One of these reasons is the thought that plans to start a family will disrupt their careers. (Seckin, 2021: 131-132). The mentality that sees women primarily as wives, mothers, or individuals who need to organize household chores is still common today. Artist Judy Chicago's project titled "The Dinner Party" (1974-79), which she completed in five years with the support of most of her female friends, represents the dinner table as the name suggests, but the plates and covers are arranged to 
remind the heroines that should not be forgotten from the past to the present. In addition to the chronological tables in which the stories of the women are told, there is a large triangular table in the exhibition area. The table, which is designed as a triangle, has plates representing 39 women. The equilateral triangle is a sign that represents that goddess from ancient times. The equilateral triangle also represents women's equality struggle. On the ground, 999 women names who left an impression in history are written. There are 13 settings on each wing. The last two plates belong to Virginia Woolf and Georgia O'Keefe. Wolf has created a woman's form in literature. O'Keefe created an analogous form in art. The meaning of it, we can express who we are and what we want (Tekin, 2018).

The 1970s were also the times when environmental movements emerged and society began to become conscious of the environment. One of the guiding factors in the formation of environmental movements is the book "Silent Spring", published in 1962 by marine biologist Rachel Carson. It has proven the harm that chemicals cause to the environment and living things, thanks to which the use of DDT is prohibited. Environmental problems have been moved to international platforms. The Greenpeace Organization (1971), which was founded by a group of activists who came together to prevent the uncontrolled hunting of whales, gained many supporters with the photos and videos taken during their actions worldwide. Even if international studies such as the reports of environmental commissions and the United Nations Climate Change Kyoto Protocol (1997) have been made, today the increase in temperature has turned into an emergency climate crisis. Most of the living species on Earth - including humans - are under threat. For this reason, it is necessary to make radical changes in production, consumption, industrial policies and lifestyle.

Ecological deterioration, which makes its impact felt in every field, has also been reflected in the mission of culture and art institutions and the expression forms of artists globally. Culture and art institutions have started to give more space to research and education studies, and artists who evaluated these researches have produced works that convey knowledge with their artistic style and creativity. Collaborations have been formed between scientists, activists and artists, and these multiple perspectives, which can see the subject with different paradigms, have created new creativity strategies. While increasing cultural and artistic activities in the context of ecology in the local and international fields are presented in physical and online media, sensitivities to reduce the carbon footprint have begun to be observed.

While nature and ecology are at the center of the subject among new genres such as Land Art, Environmental Art, Eco Art, and Bio Art, artists have included scientific tools, organic materials, video-sound recordings and software in their production. The diversity in the artist profile has been referred to by definitions such as scientist-artist, researcher-artist, eco activist artist, ecofeminist. The term ecofeminism was coined in 1974 by the French feminist Françoise d'Eaubonne. D'Eaubonne made connections between the oppression of women and the oppression of nature. "For ecofeminists, there is a connection between man's domination over women and man's dominance over nature. For them, it is androcentrism, not anthropocentrism that is responsible for the destruction of nature." (Çuçen, 2011: 9). The reason why it is called anthropocentrism indicates that people consider themselves and their intelligence superior to nature and use it for their own interests. This approach started with the Age of Enlightenment and increased with the 
Industrial Revolution. The reckless exploitation of nature, the great destruction of human activities on earth, is now named with a new geological period: Anthropocene, that is, the Human Age.

According to the ecofeminist framework, what is referred to as human is actually a maledominated perspective and action. "Man is placed above nature, man above woman, and mind above emotion. Such a conceptual framework legitimizes the subordination of women and nature. Therefore, the fate of women and nature is the same. Therefore, in order to reconceptualize man's relationship with nature, these hierarchies and dualities must be destroyed." says Abdülkadir Çuçen in his article titled "Deep Ecology". (Çuçen, 9). Andrew Dobson also made a similar definition in his work "Ecologism": he states that "the colonization of nature is related to the colonization of women and the structures and justifications for domination are similar in both cases". (Dobson, 2016: 291).

In the studies conducted for ecological transformation, it has been revealed that the countries in the African continent do not cause ecological degradation, but they are affected by this situation. Colonial policies and economic injustice are damaging the geography and society. However, local production and consumption offered as a solution proposal has already existed in these geographies and cultures for years. Vandana Shiva, author of the book "Living in Violence: Women, Ecology and Survival" on ecology and feminism, makes striking observations: "Ecology movements are political movements for a nonviolent world order based on the principle of nature conservation to preserve survival options. These are local movements, but their success comes from their ability to create non-local effects. They only demand the right to survive, but this minimum demand is tantamount to the right to live in a peaceful and just world. The success of these grassroots movements is linked to survival as a global issue. Unless ecologically reconstructed on the basis of worldviews and lifestyles, peace and justice will continue to be violated and the survival of humanity will be threatened." (Shiva, 2015: 85). In the same book, Vandana Shiva mentions that women are an integral part of nature in Indian culture, imagination and practice. It is fed by the feminine of nature to produce life and make a living. Women's knowledge is an ecological and pluralistic knowledge that reflects both the diversity of natural systems and the cultures created by nature-based life (Shiva, 89-91).

\section{Woman Artists in Eco Art}

In Greek mythology, Demeter is the goddess of agriculture, fertility and seasons, and is depicted with ears of wheat. Its equivalent in Anatolian culture is Cybele. It is a representation of abundance and fertility. Ecofeminist artists focus on women-nature connections. That's why most of the examples were chosen from women artists who act and produce in nature or related to nature. One of them, Agnes Denes, known for "Wheatfield - A Confrontation" (1982) planted wheat on an idle two-acre field in Manhattan, New York, near the World Trade Center. According to the artist, this work represented "food, energy, trade, world trade and economy". (Brown, 2014: 14). The seeds, which are the result of this action, which draws attention to food, hunger, mismanagement and ecological concerns, were distributed to visitors in exhibitions circulating in many cities of the world. This project has also been one of the pioneers of agricultural production as an art form. Inspired by Denes, the artists created breathing spaces in 
the city by planting plants suitable for the habitat of the regions they are in. For example, Carmen Bauer, the art curator of The Nature of Cities, a platform that brings together artists as well as scientists, academics and artists working on nature and discussing multi-faceted formations on ecology, examines the endemic vegetation of the cities and created awareness areas.

"Art and nature are brothers, they are branches of a tree," says John Fowles in his book "Trees". (Fowles, 2020:42). "As we watch it, it rewrites, reformulates, repaints and re-photographs itself, so to speak." (Fowles: 45). The roots of the trees communicate with each other through fungi. There is a rhizomatic information and communication network under the soil. Trees in the city are mostly located on the sidewalks, between the buildings. Artist Katie Holten, in her work titled "Tree Museum" (2009), deals with the trees on the seven-kilometer Grand Concourse Boulevard and the relationship of the residents with these trees. She firstly takes pictures of trees, draws illustrations, and determines the age and type of trees. Afterwards, she collects memories and stories about trees by meeting with people living or working around the boulevard. On the other hand, she records the sounds of animals living in trees. She transforms Concourse Boulevard into a "museum without walls" by reading the information signs she places in the trees or listening to them through an app installed on their mobile phones. Holten thus made the presence of trees visible. Personal memories about trees serve to remember the personal experiences of those who visit this open air museum. We remember the trees that we benefited from, ate the fruit of, met under the tree, and witnessed its growth. Not only in the personal context, but also the traces of the collective memory are revealed in this Holten project. (Brown, 2014: 42).

Another work belongs to Vaughn Bell, who brings nature together in the exhibition space. Building our need for green spaces that feed urban life into vegetal lanterns, Bell makes visitors feel how the air we breathe should actually be. "These jobs address our need to both dominant and care for our natural environment. These are miniature versions of public parks developed in the 19th century - an attempt to create and preserve artificial nature within the city" (Brown, 2014: 203).

The most common actions in the context of ecological art are seed bombardment and the cultivation of local plants and their distribution to people in public spaces. Seed bombs reveal that fruit seeds or flower seeds enrich the surrounding flora with a simple action. On the other hand, the plants donated in public areas create an awareness in the society about the importance of growing and evaluating local plants.

\section{Neri Oxman's Nature Designs}

Although some of the ecological artworks provide data on how we destroy nature, most of them show that it is possible to re-integrate with nature by raising awareness. Neri Oxman (1976), a professor at the MIT Media Lab, has made extraordinary designs in this regard. Her designs inspired by nature have turned into nature itself in her latest works. She has designed biomaterials by blending art, science, engineering and design. The concept of "Material Ecology", as defined by her, is a new form of biology that creates its own organic environment. To understand the concept, let's look at how she developed the clothing design called "Wanderer": We combined two microorganisms in our clothing. The first one, called cyanobacteria, is present in the oceans, in our fresh water sources. The second, e.coli, is found in our digestive system. One converts 
light into sugar, and the other consumes that sugar to produce biofuels that can benefit our environment. So much so that these two microorganisms do not interact at all in the natural environment. They were produced here for the first time to meet for the first time in our outfit. Think of it as an evolution created by design, not by natural selection. (Oxman, 2015).

By observing and analyzing the functioning of nature and living things, Oxman, researching alternative production and construction methods compatible with nature's methods, applied the cultivation method as opposed to the structures in which the parts are combined. For example, Silk Pavillon (2013) was built using 6500 silkworms. Silkworms weaved silkworms to fill the gaps of the structure, of which a robotic arm formed the silk skeleton. In the silk industry, all silkworms are killed by boiling the cocoons. In this project, silkworms were not killed, and enough silkworms were obtained to build the next domes. "Thanks to the Silk Pavillion, we have developed an approach to both living and producing together. In other words, while the product was created in this project, the life cycle also repeated" says Oxman (Dadich, 2017). Instead of beautiful designs that imitate the form of nature, she wants to adapt the designs that allow nature to complete its cycle without disturbing its functioning. "I invite everyone to a new era of design and a new creative understanding that demands that we mother nature for the first time." (Oxman, 2015).

Oxman thinks that scientific discoveries are actually equivalent in mythology. For example, Leonardo da Vinci's wings are in the myth of Icarus, and organ transplantation is in the myth of Prometheus, whose liver is regenerated every night after being eaten by an eagle. The events and characters of mythology and fantastic literature, as well as nature, inspired her own designs. One of the prototypes, "Medus 1", is a design for a protective helmet inspired by the head of the gorgon, a chthonic monster of Greek myth. Another of Oxman's prototype constructions is "Remora", which takes its title from the marine animal and its related myths of ancient seafaring. It was believed that a remora fish stopped a moving ship. Oxman designed the series "Imaginary Beings: Mythologies of the Not Yet" (2012) inspired by the book "The Book of Imaginary Beings" by Argentine author Jorge Luis Borges, who is considered one of the pioneers of the Magical Realism movement. "Oxman postulates that futuristic design is rooted in fantasy and myth and presents her prototypes as narrative tools, each presenting a potential personalized augmentation that confers a supernatural kind of function, such as flight or becoming invisible." (Myers, 2015: 54).

\section{Conclusion}

Nature has inspired artists with its beauty over the years. The plants and animals in nature were usually painted by women. However, the works of Elizabeth Blackwell, Maria Sibylla Merian and many others have been considered as important sources in botanical science due to their scope and content. Even though women were more visible in science and art in the 20th century, they had to work harder than men. Judy Chicago's work titled "Dinner Party", which she completed in 1979, has made a big impact in the art circle in terms of reminding women of history and expressing their importance. On the other hand, the 1970s witnessed environmental actions by non-governmental organizations and activists in a global context. Artists have also produced works that look at nature and the environment from a new perspective, both in nature and in art galleries. Author Françoise d'Eaubonne defined the concept of ecofeminism in her 1974 article. 
Nature and women have been exposed to the results of the male-dominated mentality and administration. The transformation of global warming into a climate crisis in the 2000s necessitated urgent restructuring. The issue of ecology has also become a dominant subject in the field of art. In addition to individual productions, many collective works were carried out, in which artists worked with scientists, researchers and local people. More emphasis was placed on research and education in art institutions, and environmentally friendly innovations were made in their own structures. It has been the mission of eco artists to grow plants, plant trees, recycle, reuse, produce works using organic materials, make them visible, raise awareness and bring suggestions. People like Neri Oxman with broad vision, who blend art and design while transforming nature into science, will shape the future.

\section{Conflict of Interest Statement}

The author declares no conflicts of interests.

\section{About the Author}

PhD Associate Professor Nezaket Tekin, Dokuz Eylül University, Fine Arts Faculty, Photography Department. Research interests: Ecology and Photography, Memory Studies, Conceptual Photography.

\section{References}

Barrett, A. (2018). Tabiata Giden Bütün Yollar. (Trans. N. Bingül), İstanbul: Yüz Yayınları Brown, D. (2014). Güncel Sanat ve Ekoloji. (Trans. E. Gözgü \& Y. Adam), İstanbul: Akbank Çüçen, A. (2011). Derin Ekoloji. https://silo.tips/download/derin-ekoloji-prof-dr-abdulkadir-enuluda-niversitesi-fen-edebiyat-fakltesi-fels 15.09.2021

Dadich, S. (2017). Abstract: The Art of Design. Season 2, Episode 2. Netflix.

Dobson, A. (2016). Ekolojizm. (Trans. C. Yücel), İstanbul: Yeni İnsan Yayınevi

Fowles, J. (2020). A ğaçlar. (Trans. S. Sertabiboğlu), İstanbul: Ayrıntı.

Kapucu, B. (2021). Botanitopya: İskoç Bitki Ressamı Elizabeth Blackwell. Podcast. Açık Radyo. https://acikradyo.com.tr/botanitopya/iskoc-bitki-ressami-elizabeth-blackwell 23.04.2021

Lotzof, K. Anna Atkin's Cyanotypes: The First Book of Photographs. London: Natural History Museum. https://www.nhm.ac.uk/discover/anna-atkins-cyanotypes-the-first-book-ofphotographs.html 22.08.2021

Myers, W. (2015). Bio Art: Altered Realities. London: Thames \& Hudson.

OSGF. Women Botanical Artists. https://artsandculture.google.com/exhibit/women-botanicalartists/WgLy8tiTry5dIQ 20.08.2021

Oxman, N. (2015). Design at the intersection of technology and biology. Ted Talks. https://www.ted.com/talks/neri oxman design at the intersection of technology and biology?language=tr 24.08.2021

Seçkin, A. (2021). Sanatın Ekonomisi. Hayalperest, İstanbul. 
Shiva, V. (2015) İnadına Canlı: Kadınlar, Ekoloji ve Hayatta Kalma. (Trans. E. Ayhan), İstanbul: Sinek Sekiz Yayınları.

Wilson, S. (2012). Art+Science Now. Thames \& Hudson, London.

Tekin, N. (2002). Çă̆daş Bir Sanat Formu Olarak Fotoğraf. Master Thesis. Dokuz Eylül University, İzmir, Turkey.

Tekin, N. (2018). Dining Tables in Contemporary Art. Poster. The 1st Biannual Conference on Food and Communication. Queen Margaret University, Edinburg.

Torres, D. Short Story Sunday. https://danitorres.typepad.com/workinprogress/2015/08/shortstory-sunday-rare-bird.html 22.08.2021 
Nezaket Tekin

ECOFEMINIST DISCOURSE AND ECO ART

Creative Commons licensing terms

Author(s) will retain the copyright of their published articles agreeing that a Creative Commons Attribution 4.0 International License (CC BY 4.0) terms will be applied to their work. Under the terms of this license, no permission is required from the author(s) or publisher for members of the community to copy, distribute, transmit or adapt the article content, providing a proper, prominent and unambiguous attribution to the authors in a manner that makes clear that the materials are being reused under permission of a Creative Commons License. Views, opinions and conclusions expressed in this research article are views, opinions and conclusions of the author(s). and European Journal of Literature, Language and Linguistics Studies shall not be responsible or answerable for any loss, damage or liability caused in relation to/arising out of conflicts of interest, copyright violations and inappropriate or inaccurate use of any kind content related or integrated into the research work. All the published works are meeting the Open Access Publishing requirements and can be freely accessed, shared, modified, distributed and used in educational, commercial and non-commercial purposes under a Creative Commons Attribution 4.0 International License (CC BY 4.0).

European Journal of Literature, Language and Linguistics Studies - Volume 5 | Issue 2 | 2021 